\title{
Pengaruh Struktur Modal dan Ukuran Perusahaan terhadap Nilai Perusahaan pada Perusahaan Sub Sektor Perdagangan Besar Barang Produksi yang Terdaftar di Bursa Efek Indonesia pada Tahun 2016 - 2018
}

\author{
Muhammad Burhanudin ${ }^{1 *}$, Wayan Cipta ${ }^{2}$ iD \\ ${ }^{123}$ Program Studi Manajemen, Fakultas Ekonomi, Universitas Pendidikan Ganesha, Singaraja, Indonesia \\ *mburhanudin0109@gmail.com ${ }^{1 *}$
}

\section{Abstrak}

Penelitian ini bertujuan untuk menguji pengaruh struktur modal dan ukuran perusahaan terhadap nilai perusahaan pada perusahaan sub sektor perdagangan besar barang produksi yang terdaftar di Bursa Efek Indonesia tahun 2016 - 2018 baik secara simultan maupun parsial. Populasi yang digunakan dalam penelitian ini adalah perusahaan sub sektor perdagangan besar barang produksi yang terdaftar di Bursa Efek Indonesia yang menyampaikan laporan keuangannya sebanyak 26 perusahaan. Desain penelitian ini adalah kuantitatif kausal sebagai pembuktian sebab akibat atau pengaruh dari struktur modal dan ukuran perusahaan sebagai variabel bebas terhadap nilai perusahaan sebagai variabel terikat. Data dikumpulkan dengan pencatatan dokumen, dan dianalisis dengan analisis regresi linier berganda. Hasil penelitian ini menunjukkan bahwa: (1) struktur modal dan ukuran perusahaan berpengaruh signifikan terhadap nilai perusahaan, (2) struktur modal berpengaruh positif dan signifikan terhadap nilai perusahaan, (3) ukuran Perusahaanl berpengaruh negatif dan signifikan terhadap nilai perusahaan.

Kata Kunci : Nilai Perusahaan, Struktur Modal, Ukuran Perusahaan

\section{Abstract}

This study aims to examine the effect of capital structure and company size on firm value in the large trade sub sector of manufactured goods listed on the Indonesia Stock Exchange in 2016 - 2018, either simultaneously or partially. The population used in this study is the sub-sector companies of large-scale production goods listed on the Indonesia Stock Exchange which submit their financial reports of 26 companies. The design of this research is causal quantitative as proof of the effect of capital structure and firm size as independent variables on firm value as the dependent variable. The data collected by documents recording, and analyzed by multiple linear regression analysis. The results showed that: (1) capital structure and firm size had a significant effect on firm value, (2) capital structure had a positive and significant effect on firm value, (3) firm size had a negative and significant effect on firm value.

Keywords: Company Value, Capital Structure, Company Size

\section{Pendahuluan}

Perkembangan bisnis yang terjadi saat ini tidak terlepas dari adanya para pesaing. Hal ini bisa dilihat dengan banyak munculnya perusahaan yang memiliki usaha yang sama, baik dalam bidang perdagangan, industri, ataupun jasa yang menyebabkan persaingan antar perusahaan semakin ketat. Dalam persaingan, perusahaan dituntut untuk dapat meningkatkan kinerjanya dan memiliki keunggulan yang kompetitif dibandingkan para pesaing, sehingga apa yang menjadi tujuannya dapat tercapai. Setiap perusahaan tentu memiliki tujuan baik jangka pendek maupun jangka panjang, tujuan jangka pendek perusahaan mencari keuntungan semaksimal mungkin dengan memanfaatkan sumber daya yang dimiliki oleh

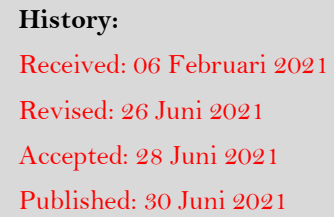

Publisher: Undiksha Press

Licensed: This work is licensed under

a Creative Commons Attribution 3.0 License

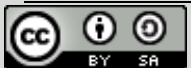


perusahaan dan tujuan jangka panjang memaksimalkan nilai perusahaan. Nilai perusahaan merupakan kondisi tertentu yang dicapai oleh suatu perusahaan dengan menggambarkan prospek perusahaan di masa mendatang. Brigham dan Houston (2011) menjelaskan bahwa nilai perusahaan sangat penting, karena nilai perusahan yang tinggi mengindikasikan bahwa kemakmuran pemegang saham juga tinggi. Harga saham yang tinggi akan diikuti juga dengan tingginya nilai perusahaan. Nilai perusahaan yang tinggi membuat investor percaya tidak hanya pada kinerja perusahaan saat ini, namun juga pada prospek perusahaan di masa mendatang (Hermuningsih, 2013). Salah satu rasio yang dapat digunakan untuk mengukur nilai perusahaan yaitu Price to Book Value (PBV). PBV merupakan rasio yang digunakan dengan membandingkan nilai saham menurut pasar dengan nilai buku ekuitas perusahaan serta menunjukkan kemampuan perusahaan dalam menciptakan nilai relatif terhadap jumlah modal yang diinvestasikan.

Sektor perdagangan, jasa, dan investas merupakan salah satu satu dari 9 sektor yang terdaftar di Bursa Efek Indonesia dan menjadi sektor yang kuat karena mencakup kebutuhan umum masyarakat sehari-hari. Bursa Efek Indonesia (BEI) mencatat bahwa sepanjang tahun 2018 keseluruhan perusahaan yang listing tahun ini, perusahaan sektor perdagangan, jasa, dan investasi cukup mendominasi dengan menyumbang sebesar $36,4 \%$, diikuti dengan sektor infrastruktur, utilitas, dan transportasi yang menyumbang $24,2 \%$, kemudian sektor property dan real estate dengan $9,1 \%$, sektor agrikultur menyumbang sebesar $6,0 \%$ dan sektor pertambangan menyumbang $3,0 \%$ (bisnis.com).

Salah satu sub sektor yang ada didalamnya yaitu sub sektor perdagangan besar barang produki. Sub Sektor ini merupakan sub sektor yang bergerak dalam bidang distributor jual beli dalam jumlah yang besar dan membuat sub sektor ini memiliki potensi besar untuk mendukung perekonomian di suatu negara, karena semakin meningkatnya daya beli masyarakat, secara tidak langsung permintaan akan barang-barang dagang juga akan meningkat. Namun, sub sektor ini memiliki permasalahan pada nilai perusahaan yang berfluktuasi. Nilai perusahaan sangat penting dan mencerminkan penilaan tersendiri bagi investor. Berdasarkan pernyataan di atas, disajikan data perbandingan nilai perusahaan yang diukur menggunakan Price to Book Value dari perusahaan sektor perdagangan, jasa, dan investasi yang terdaftar di Bursa Efek Indonesia pada tahun 2016 - 2018 yang dapat dilihat pada Tabel 1.1

Tabel 1.1 Data Perbandingan Price to Book Value pada Sektor Perdagangan, Jasa, dan Investasi yang Terdaftar di Bursa Efek Indonesia Tahun 2016 - 2018

\begin{tabular}{llcccc}
\hline \multirow{2}{*}{ No } & \multirow{2}{*}{ Nama Sub Sektor } & \multicolumn{3}{c}{ Rata-Rata Price to Book Value } & \multirow{2}{*}{ (PBV) } \\
\cline { 3 - 5 } & & $\mathbf{2 0 1 6}$ & $\mathbf{2 0 1 7}$ & $\mathbf{2 0 1 8}$ & \\
\hline \multirow{2}{*}{1} & Perdagangan Besar Barang Produksi & $2,25 \%$ & $0,41 \%$ & $1,54 \%$ & Fluktuasi \\
\hline 2 & Perdagangan Eceran & $1,60 \%$ & $1,68 \%$ & $1,71 \%$ & Meningkat \\
\hline
\end{tabular}

Sumber: Laporan Keuangan di Bursa Efek Indonesia (data diolah)

Berdasarkan pada Tabel 1.1 di atas menunjukkan bahwa price to book value pada sub sektor perdagangan besar barang produksi pada tahun 2017 mengalami penurunan sebesar $0,81 \%$ dan pada tahun 2018 mengalami kenaikan sebesar 2,75\%. Hal ini menunjukkan bahwa sub sektor perdagangan besar barang produksi mengalami fluktuasi pada nilai perusahaannya dibandingkan dengan sub sektor perdagangan eceran yang mengalami peningkatan nilai perusahaan. Dengan demikian, penelitian ini menggunakan sub sektor perdagangan besar barang produksi. Maka dari itu, perlu mengetahui faktor-faktor yang mempengaruhi nilai perusahaan pada sub sektor perdagangan besar barang produksi. 
Faktor yang mempengaruhi nilai perusahaan Setia (2008) yaitu keputusan pendanaan, kebijakan dividen, keputusan investasi, struktur modal, profitabilitas, leverage, pertumbuhan perusahaan, ukuran perusahaan. Prastuti dan Sudiartha (2016) menyatakan bahwa faktor yang mempengaruhi nilai perusahaan yaitu struktur modal, kebijakan dividen, dan ukuran perusahaan. Alfredo dkk (2011) menyatakan bahwa faktor yang mempengaruhi nilai perusahaan yaitu keputusan pendanaan, kebijakan dividen, keputusan investasi, struktur modal, pertumbuhan perusahaan, dan ukuran perusahaan. Sedangkan, Hasnawati (2015) menyatakan faktor yang mempengaruhi nilai perusahaan meliputi keputusan keuangan, ukuran perusahaan, dan struktur kepemilikan. Dalam Penelitian ini hanya memfokuskan menggunakan variabel struktur modal dan ukuran perusahaan yang mempengaruhi nilai perusahaan. Karena pada penelitian Prastuti dan Sudiartha (2016) variabel struktur modal berpengaruh dominan terhadap nilai perusahaan, serta pada penelitian Hasnawati (2015) variabel ukuran perusahaan yang berpengaruh dominan terhadap nilai perusahaan.

Salah satu keputusan penting yang dihadapi oleh manager keuangan adalah keputusan atas struktur modal. Struktur modal merupakan kombinasi hutang dan ekuitas yang bersifat jangka panjang dalam struktur keuangan perusahaan. Menurut Susanto (2016) menyatakan bahwa struktur modal menjadi faktor penting di dalam perusahaan, karena terkait dengan baik buruknya struktur modal yang nantinya akan berpengaruh terhadap nilai perusahaan. Suatu perusahaan yang memiliki struktur modal yang tidak baik dan memiliki hutang yang sangat besar, tentu memberikan beban yang berat kepada perusahaan. Penggunaan hutang akan mempengaruhi kinerja perusahaan karena semakin tinggi beban, risiko yang ditanggung juga besar dan pengunaan hutang akan mempengaruhi tingkat kepercayaan investor terhadap perusahaan. Penelitian yang dilakukan oleh Meidiawati dan Mildawati (2016) pada Perusahaan Manufaktur di Bursa Efek Indonesia (BEI) menyatakan bahwa struktur modal berpengaruh positif dan signifikan terhadap nilai perusahaan. Penelitian lain yang dilakukan oleh Hamidy dkk (2015) pada Perusahaan Property dan Real Estate di Bursa Efek Indonesia (BEI) menyatakan bahwa struktur modal berpengaruh positif dan signifikan terhadap nilai perusahaan. Namun, penelitian lainnya yang dilakukan oleh Utomo dan Cristy (2017) pada Perusahaan LQ 45 di Bursa Efek Indonesia (BEI) menyatakan bahwa struktur modal berpengaruh negatif dan signifikan terhadap nilai perusahaan. Serta penelitian yang dilakukan oleh Situmeang dan Wiagustini (2018) pada Perusahaan BUMN Go-Public yang menyatakan bahwa struktur modal berpengaruh negatif dan signifikan terhadap nilai perusahaan.

Ukuran perusahaan merupakan kondisi perusahaan yang dapat dilihat dari besar kecilnya seluruh total aset yang dimiliki. Dewi dan Badjra (2017) menyatakan bahwa perusahaan dengan total aset yang besar akan memudahkan manajemen dalam mempergunakan aset perusahaan. Kemudahan mengendalikan perusahaan tersebut akan meningkatkan nilai perusahaan. Perusahaan sendiri dapat dibedakan menjadi dua yaitu perusahaan berskala besar dan perusahaan berskala kecil. Perusahaan yang memiliki skala besar lebih mampu membuat perusahaan untuk tetap stabil, karena memiliki kontrol yang lebih baik terhadap kondisi pasar dan sangat kuat dalam menghadapi fluktuasi ekonomi sehingga mampu menghadapi persaingan ekonomi, dibandingkan dengan perusahaan yang berskala kecil. Penelitian yang dilakukan oleh Chusnitah dan Retnani (2017) pada Perusahaan Otomotif di Bursa Efek Indonesia (BEI) menyatakan bahwa ukuran perusahaan berpengaruh positif dan signifikan terhadap nilai perusahaan. Penelitian lain yang dilakukan oleh Novari dan Lestari (2016) pada sektor Property dan Real Estate di Bursa Efek Indonesia (BEI) menyatakan bahwa ukuran perusahaan berpengaruh positif dan signifikan terhadap nilai perusahaan. Namun, penelitian lainnya yang dilakukan Irawan dan Kusuma (2019) pada Perusahaan Manufaktur di Bursa Efek Indonesia (BEI) menyatakan bahwa ukuran perusahaan berpengaruh negatif dan signifikan terhadap nilai perusahaan. Serta Penelitian 
yang dilakukan oleh Ukhriyawati dan Dewi (2019) pada Perusahaan LQ-45 di Bursa Efek Indonesia (BEI) yang menyatakan bahwa ukuran persahaan berpengaruh negatif dan signifikan terhadap nilai perusahaan.

Berdasarkan uraian latar belakang di atas, maka penelitian tertarik untuk mengambil judul Pengaruh Struktur Modal dan Ukuran Perusahaan Terhadap Nilai Perusahaan Pada Perusahaan Sub Sektor Perdagangan Besar Barang Produksi yang Terdaftar di Bursa Efek Indonesia”. Penelitian ini mengambil data tahun 2016 - 2018. Berdasarkan latar belakang masalah di atas maka rumusan masalah yang dapat diambil yaitu sebagai berikut: (1) Bagaimana pengaruh struktur modal dan ukuran perusahaan secara simultan terhadap nilai perusahaan pada perusahaan Sub Sektor Perdagangan Besar Barang Produksi yang terdaftar di Bursa Efek Indonesia tahun 2016 - 2018. (2) Bagaimana pengaruh struktur modal secara parsial terhadap nilai perusahaan pada perusahaan Sub Sektor Perdagangan Besar Barang Produksi yang terdaftar di Bursa Efek Indonesia tahun 2016 - 2018. (3) Bagaimana pengaruh ukuran perusahaan secara parsial terhadap nilai perusahaan pada perusahaan Sub Sektor Perdagangan Besar Barang Produksi yang terdaftar di Bursa Efek Indonesia tahun 2016 2018.

Berdasarkan latar belakang dan rumusan masalah, adapun tujuan penelitian ini adalah untuk mengetahui hal-hal sebagai berikut: (1) Pengaruh struktur modal ukuran perusahaan secara simultan terhadap nilai perusahaan pada perusahaan Sub Sektor Perdagangan Besar Barang Produksi yang terdaftar di Bursa Efek Indonesia. (2) Pengaruh secara parsial struktur modal terhadap nilai perusahaan pada perusahaan Sub Sektor Perdagangan Besar Barang Produksi yang terdaftar di Bursa Efek Indonesia. (3) Pengaruh secara parsial ukuran perusahaan terhadap nilai perusahaan pada perusahaan Sub Sektor Perdagangan Besar Barang Produksi yang terdaftar di Bursa Efek Indonesia.

\section{Pengaruh Struktur Modal dan Ukuran Perusahaan dengan Nilai Perusahaan}

Hubungan antara struktur modal dan ukuran perusahaan terhadap nilai perusahaan dikemukakan oleh Sawir (2004) apabila struktur modal meningkat dan ukuran perusahaan tinggi maka nilai perusahaan akan cenderung tinggi begitu juga sebaliknya apabila ukuran perusahaan menurun dan struktur modalnya rendah maka nilai perusahaan akan cenderung rendah. Pernyataan tersebut didukung juga oleh penelitian yang dilakukan Indrawati dan Suhendro (2006) bahwa besarnya struktur modal dan keputusan perusahaan dalam menetapkan besar kecilnya ukuran perusahaan yang digunakan perusahaan dalam operasionalnya menentukan nilai perusahaan yang diinginkan perusahaan tersebut.

$H_{1}$ : Ada pengaruh secara simultan struktur modal dan ukuran perusahaan terhadap nilai perusahaan pada perusahaan sub sektor perdagangan besar barang produksi di Bursa Efek Indonesia

\section{Pengaruh Struktur Modal dengan Nilai Perusahaan}

Pada tahun1950-an, Modigliani dan Miller menentang pandangan tradisional struktur modal. Mereka berpendapat bahwa struktur modal tidak relevan atau tidak mempengaruhi nilai perusahaan. Kemudian pada awal tahun1960-an, Modigliani dan Miller memasukkan faktor pajak kedalam analisis mereka sehingga mendapat kesimpulan bahwa nilai perusahaan dengan hutang akan lebih tinggi dibandingkan dengan nilai perusahaan tanpa hutang. Kenaikkan tersebut dikarenakan adanya penghematan pajak. Hal ini sesuai dengan Trade-off theory yang disampaikan Dewi dan Wirajaya (2013) yang menjelaskan jika posisi struktur modal perusahaan berada dibawah titik optimal maka setiap penambahan hutang akan meningkatkan nilai perusahaan. Sebaliknya, jika posisi struktur modalnya berada di atas titik optimal maka setiap penambahan hutang akan menurunkan nilai perusahaan. Dalam penelitian Suranta dan Mediastuty (2003) menyatakan bahwa struktur modal mempunyai 
pengaruh positif dan signifikan terhadap nilai perusahaan. Apabila struktur modal meningkat, maka akan mempengaruhi peningkatan nilai perusahaan. Hasil penelitian ini sejalan dengan penelitian yang dilakukan oleh Meidiawati dan Mildawati (2016) yang menyatakan bahwa struktur modal berpengaruh positif dan signifikan terhadap nilai perusahaan.

$\mathrm{H}_{2}$ : Ada pengaruh secara parsial struktur modal terhadap nilai perusahaan pada perusahaan sub sektor perdagangan besar barang produksi di Bursa Efek Indonesia.

\section{Pengaruh Ukuran Perusahaan dengan Nilai Perusahaan}

Ukuran perusahaan merupakan salah satu faktor yang dapat mempengaruhi nilai perusahaan. Perusahaan yang berskala besar cenderung akan menarik minat banyak investor yang akan berimbas pada nilai perusahaan, sehingga besar kecilnya ukuran perusahaan secara langsung dapat berpengaruh terhadap nilai dari perusahaan tersebut. Menurut Riyanto (2001) semakin besar ukuran perusahaan, maka ada kecenderungan lebih banyak investor yang menaruh perhatian pada perusahaan tersebut, sehingga akan meningatkan nilai perusahaan di mata investor. Karena perusahaan yang besar cenderung memiliki kondisi yang stabil. Teori ini sejalan dengan hasil penelitian yang telah dilakukan oleh Novari dan Lestari (2016) yang menemukan bahwa ukuran perusahaan berpengaruh positif dan signifikan terhadap nilai perusahaan.

H3: Ada pengaruh secara parsial ukuran perusahaan terhadap nilai perusahaan pada perusahaan sub sektor perdagangan besar barang produksi di Bursa Efek Indonesia

\section{Metode}

Penelitian ini dilakukan untuk memperoleh gambaran tentang pengaruh struktur modal dan ukuran perusahaan terhadap nilai perusahaan pada perusaahaan Sub Sektor Perdagangan Besar Barang Produksi yang terdaftar di Bursa Efek Indonesia tahun 2016 - 2018. Jenis penelitian yang digunakan adalah penelitian kuantitatif kausal. Penelitian kuantitaif kausal merupakan penelitian pendekatan ilmiah terhadap pengambilan keputusan manajerial dan ekonomi yang bertujuan untuk mendapatkan bukti hubungan sebab akibat atau pengaruh dari variabel-variabel penelitian.

Variabel dalam penelitian ini dibagi menjadi dua yaitu variabel bebas dan variabel terikat. Variabel bebas dalam penelitian ini adalah struktur modal (x1) dan ukuran perusahaan (x2), sedangkan variabel terikat dalam penelitian ini adalah nilai perusahaan $(Y)$. Untuk membantu proses pengolahan data secara tepat dan cepat, maka pengolahan data dilakukan dengan menggunakan bantuan dengan program computer Statistical Package for Social Science (SPSS) 20 for windows.

Penelitian ini dilakukan pada perusahaan perdagangan besar barang produksi yang terdaftar di Bursa Efek Indonesia (BEI) yang menyampaikan laporan keuangannya secara lengkap sebanyak 26 perusahaan pada tahun 2016 - 2018 dan jenis data yang digunakan adalah data kuantitatif berupa data sekunder yang diperoleh dari laporan keuangan yang dipublikasikan perusahaan Sub Sektor Perdagangan Besar Barang Produksi di Bursa Efek Indonesia (BEI) yang diakses melalui www.idx.co.id.

Teknik analisis data yang digunakan adalah analisis regresi linier berganda. Data yang akan dianalisis dalam penelitian ini berkaitan dengan hubungan antar variabel-variabel. Analisis data dilakukan secara kuantitatif dengan tahapan yaitu: (1) uji asumsi klasik, (2) analisis regresi linier berganda dan (3) koefisien determinasi. Tujuannya adalah menetapkan apakah variabel bebas mempunyai hubungan dengan variabel terikatnya, penetapan tingkat signifikansi, dan diakhiri dengan penelitian dasar penarikan kesimpulan melalui penerimaan atau penolakan hipotesis.

\section{Hasil dan Pembahasan}


Analisis Regresi Linear Berganda

Adapun hasil pengujian hipotesis dengan menggunakan analisis regresi linier berganda pada struktur pengaruh struktur modal dan ukuran perusahaan terhadap nilai perusahaan pada perusahaan sub sektor perdagangan besar barang produksi yang terdaftar di Bursa Efek Indonesia dapat dilihat pada Gambar 1.1

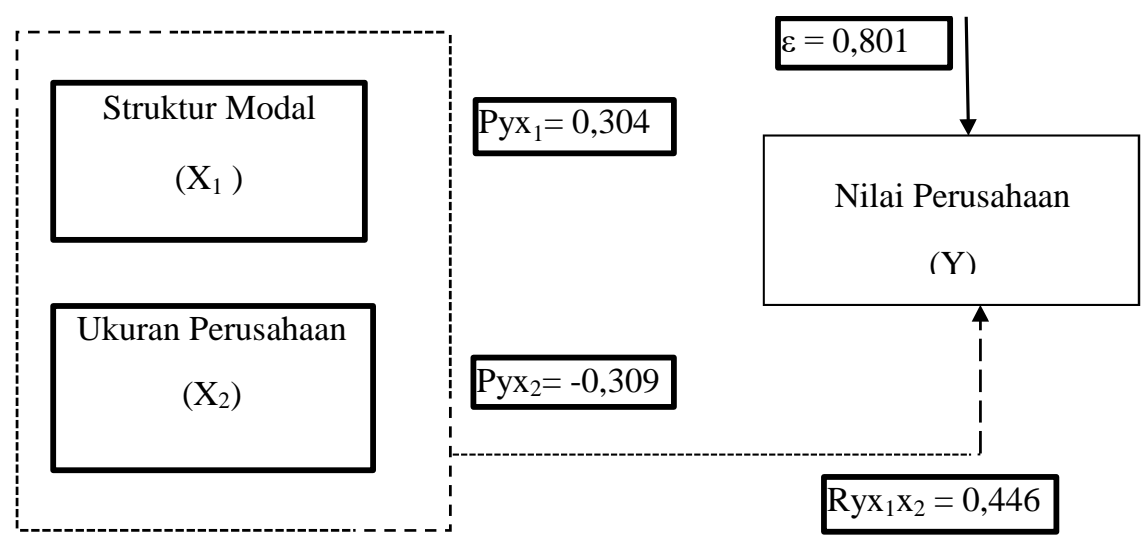

Gambar 1.1 Struktur Pengaruh Struktur Modal (X1), Ukuran Perusahaan (X2 ) terhadap Nilai Perusahaan (Y).

Hipotesis penelitian pertama "Ada pengaruh simultan dari struktur modal dan ukuran perusahaan terhadap nilai perusahaan" berdasarkan rekapan hasil uji regresi berganda menunjukan hasil Ryx1x $2=0,446$ dengan p-value $0,000<$ alpha 0,05 dengan demikian keputusan yang diambil adalah Ho ditolak dan Ha diterima. Hasil ini berarti secara simultan ada pengaruh struktur modal dan ukuran perusahaan terhadap nilai perusahaan pada perusahaan Sub Sektor Perdagangan Besar Barang Produksi yang terdaftar di Bursa Efek indonesia tahun 2016 - 2018. Besarnya sumbangan pengaruh simultan dari struktur modal dan dan ukuran perusahaan terhadap nilai perusahaan sebesar 0,199 (19,9\%). Hasil tersebut menunjukkan bahwa sebesar 19,9\% nilai perusahaan dipengaruhi oleh struktur modal dan ukuran perusahaan, sementara itu sebesar $0,801(80,1 \%)$ dipengaruhi oleh variabel lain.

Hipotesis penelitian kedua "Ada pengaruh dari struktur modal terhadap nilai perusahaan" berdasarkan rekapan hasil uji regresi berganda diperoleh hasil yaitu besarnya pengaruh struktur modal sebesar 0,304 (30,4\%) dengan p-value 0,007 > alpha 0,05 yang menyatakan bahwa Ho ditolak dan Ha diterima. Hasil ini menunjukkan adanya pengaruh positif dan signifikan struktur modal terhadap nilai perusahaan pada perusahaan Sub Sektor Perdagangan Besar Barang Produksi yang terdaftar di Bursa Efek Indonesia tahun 2016 2018. Besar sumbangan pengaruh pengaruh struktur modal terhadap nilai perusahaan sebesar $0,092(09,2 \%)$.

Hipotesis penelitian ketiga "Ada pengaruh dari ukuran perusahaan terhadap nilai perusahaan" berdasarkan rekapan hasil uji regresi berganda diperoleh hasil yaitu besarnya pengaruh ukuran perusahaan sebesar $-0,309$ (-30,9\%) dengan p-value 0,006 > alpha 0,05 menyatakan bahwa Ho ditolak dan Ha diterima. Hasil ini menunjukkan adanya pengaruh negatif dan signifikan ukuran perusahaan terhadap nilai perusahaan pada perusahaan Sub Sektor Perdagangan Besar Barang Produksi yang terdaftar di Bursa Efek Indonesia tahun 2016 - 2018. Besar sumbangan pengaruh ukuran perusahaan terhadap nilai perusahaan sebesar $-0,095(-09,5 \%)$.

Hasil penelitian ini menunjukkan bahwa secara simultan struktur modal dan ukuran perusahaan terhadap nilai perusahaan pada perusahaan Sub Sektor Perdagangan Besar Barang Produksi yang terdaftar di Bursa Efek Indonesia tahun 2016 - 2018. Hasil ini menunjukkan apabila kedua variabel mengalami kenaikan, maka akan diikuti dengan 
kenaikan nilai perusahaan. Hal ini berarti perusahaan memperhatikan kedua variabel bebas tersebut dalam menentukan nilai perusahaan. Hasil penelitian ini sejalan dengan teori yang dikemukakan oleh Sawir (2004) apabila struktur modal meningkat dan ukuran perusahaan tinggi maka nilai perusahaan akan cenderung tinggi begitu juga sebaliknya apabila struktur modal dan ukuran perusahaan menurun dan rendah maka nilai perusahaan juga akan cenderung rendah. Pernyataan tersebut didukung juga oleh penelitian yang dilakukan Indrawati dan Suhendro (2006) bahwa besarnya struktur modal dan keputusan perusahaan dalam menetapkan besar kecilnya ukuran perusahaan yang digunakan perusahaan dalam operasionalnya menentukan nilai perusahaan yang diinginkan perusahaan tersebut.

Hasil penelitian yang telah dilakukan menunjukkan bahwa ada pengaruh positif dan signifikan struktur modal terhadap nilai perusahaan pada perusahaan Sub Sektor Perdagangan Besar Barang Produksi yang terdaftar di Bursa Efek Indonesia tahun 2016 - 2018. Hasil penelitian ini sejalan dengan dengan Trade-off theory yang disampaikan Dewi dan Wirajaya (2013) yang menjelaskan jika posisi struktur modal perusahaan berada dibawah titik optimal maka setiap penambahan hutang akan meningkatkan nilai perusahaan. Sebaliknya, jika posisi struktur modalnya berada di atas titik optimal maka setiap penambahan hutang akan menurunkan nilai perusahaan. Dalam penelitian Suranta dan Mediastuty (2003) menyatakan bahwa struktur modal mempunyai pengaruh positif dan signifikan terhadap nilai perusahaan. Apabila struktur modal meningkat, maka akan mempengaruhi peningkatan nilai perusahaan. Hasil penelitian ini diperkuat dengan hasil penelitian yang dilakukan oleh Meidiawati dan Mildawati (2016) yang menyatakan bahwa struktur modal berpengaruh positif dan signifikan terhadap nilai perusahaan.

Dalam penelitian ini ukuran perusahaan menunjukkan bahwa ada pengaruh negatif dan signifikan terhadap nilai perusahaan pada perusahaan Sub Sektor Perdagangan Besar Barang Produksi yang terdaftar di Bursa Efek Indonesia tahun 2016 - 2018. Hasil penelitian ini sejalan dengan teori yang dikemukakan oleh Ramadhonah dkk (2019) yang menjelaskan bahwa persepsi investor kepada perusahaan yang memiliki total aset yang besar cenderung negatif, karena investor menganggap perusahaan dengan total aset yang besar lebih menetapkan laba ditahan dibandingkan membagikannya dalam bentuk dividen kepada para pemegang saham, sehingga hal tersebut tentu akan mempengaruhi nilai suatu perusahaan. Penelitian ini diperkuat dengan hasil penelitian yang dilakukan oleh Irawan dan Kusuma (2019) yang menyatakan bahwa ukuran perusahaan berpengaruh negatif dan signifikan terhadap nilai perusahaan.

\section{Simpulan dan Saran}

Berdasarkan hasil pembahasan yang telah dilakukan pada bab sebelumnya, maka dapat ditarik beberapa kesimpulan yaitu struktur modal dan ukuran perusahaan secara simultan berpengaruh signifikan terhadap nilai perusahaan pada perusahaan sub sektor perdagangan besar barang produksi yang terdaftar di bursa efek indonesia tahun 2016 - 2018, struktur modal secara parsial berpengaruh positif dan signifikan terhadap nilai perusahaan pada perusahaan sub sektor perdagangan besar barang produksi yang terdaftar di bursa efek indonesia tahun 2016 - 2018, dan ukuran perusahaan secara parsial berpengaruh negatif dan signifikan terhadap nilai perusahaan pada perusahaan sub sektor perdagangan besar barang produksi yang terdaftar di Bursa Efek Indonesia tahun 2016 - 2018.

Berdasarkan hasil simpulan yang telah dikemukakan, maka saran yang dapat dianjurkan yaitu Bagi para peneliti selanjutnya diharapkan dapat menggunakan variabel lain yang mampu mempengaruhi nilai perusahaan, seperti: leverage, pertumbuhan perusahaan ataupun kebijakan dividen serta dapat menambahkan periode penelitian agar lebih mudah melihat perkembangan nilai perusahaan. Penelitian ini meneliti sektor perdagangan besar barang 
produksi yang terdaftar di Bursa Efek Indonesia tahun 2016 - 2018, kemudian bagi investor yaitu dalam melakukan investasi, para investor diharapkan dapat mempertimbangkan dan menganalisis terlebih dahulu dua aspek penting yang dapat mempengaruhi nilai perusahaan yaitu struktur modal dan ukuran perusahaan yang nanti berguna sebagai pengambilan keputusan yang dilakukan oleh seorang investor sebelum menanamkan modalnya pada suatu perusahaan. Oleh karena itu, investor diharapkan dapat memperhatikan risiko yang nanti akan terjadi, sehingga investor dapat memilih perusahaan yang tepat untuk dijadikan sebagai tempat berinvestasi.

\section{Daftar Pustaka}

Alfredo, Mahendra, dkk. 2011. Pengaruh Kinerja Keuangan terhadap Nilai Perusahaan (Kebijakan Dividen Sebagai Variabel Moderating) Pada Perusahan Manufaktur di BEI. E-Jurnal Unud, Vol. 6, No. 2.

Ambarwati, S. D. A. 2010. Manajemen Keuangan Lanjutan. Yogyakarta: Graha Ilmu.

Arief, Tegar. 30 Agustus 2018. “Antrean IPO Kian Panjang, Sektor Perdagangan Mendominasi”. Tersedia pada https://m.bisnis.com/amp/read/20180830/192/833263/antrean-ipo-kian-panjang-sektorperdagangan-mendominasi.

Ayuningrum, Niken. 2017. Pengaruh Struktur Modal, Pertumbuhan Perusahaan terhadap Nilai Perusahaan dengan Profitabilitas sebagai Variabel Intervening Pada Perusahaan Manufaktur yang Terdaftar di Bursa Efek Indonesia. Jurnal Riset Terapan Akuntansi, Vol. 1, No.1, ISSN: 2579-9690.

Brigham, Eungene F dan Joel F Houston. 2011. Dasar Dasar Manajemen Keuangan, Edisi Sebelas. Salemba Empat.

Brigham, Eungene F dan Joel F Houston. 2001. Manajemen Keuangan. Jakarta: PT. Erlangga.

Bursa Efek Indonesia. 2016 - 2019. Statistic Indonesia Stock Exchange (IDX). terdapat di www.idx.co.id

Chusnitah, Nur Maghfirotu dan Endang Dwi Retnani. 2017. Pengaruh Struktur Modal, Pertumbuhan Perusahaan, Ukuran Perusahaan dan Profitabilitas terhadap Nilai Perusahaan. Jurnal Ilmu dan Riset Manajemen, Vol. 6, No. 11, ISSN: 2460-0585.

Dewi, A. A. A. K dan I. D. Badjra. 2017. Pengaruh Profitabilitas, Aktiva Tidak Berwujud, Ukuran Perusahaan, dan Struktur Modal terhadap Nilai Perusahaan. E-Jurnal Manajemen Unud, Vol. 6, No. 4, ISSN: 2302-8912, hal: 2161-2190.

Dewi, Ayu Sri M. dan Ary Wirajaya. 2013. Pengaruh Struktur Modal, Profitabitas, dan Ukuran Perusahaan Pada Nilai Perusahaan. E-Journal Akuntansi Universitas Udayana, Vol 4, No. 2, ISSN: 2302-8556, hal: 358-372.

Ghozali, Imam. 2018. Aplikasi Analisis Multivariate dengan Program IBM SPSS 25, Edisi Sembilan. Semarang: Universitas Diponogoro.

Hamidy, Rahman Rusdi, dkk. 2015. Pengaruh Struktur Modal terhadap Nilai Perusahaan Dengan Profitabilitas Sebagai Variabel Intervening Pada Perusahaan Property and Real Estate di Bursa Efek Indonesia. E-Jurnal Ekonomi dan Bisnis Udayana, Vol. 4, No. 5, ISSN:2337-3067, hal: 665-682.

Hasnawati, Sri. 2015. Keputusan Keuangan, Ukuran Perusahaan terhadap Nilai Perusahaan

Publik di Indonesia, Vol. 17, No. 1, ISSN: 1411-1438. 
Hermuningsih, Sri. 2013. Pengaruh Profitabilitas, Growth Opportunity, Struktur Modal terhadap Nilai Perusahaan Pada Perusahaan Publik di Indonesia. Buletin Ekonomi Moneter dan Perbankan, hal: 128-147.

Horne, James C. V dan John M Wachowicz. 2013. Fundamental of Financial Manajemen. Salemba Empat.

Indrawati, Titik. dan Suhendro. 2006. Determinasi Capital Structure Pada Perusahaan Manufaktur di Bursa Efek Indonesia Periode 2000-2004. Jurnal Akuntansi Dan Keuangan Indonesia, Vol. 3, No7, hal: 77-105.

Irawan, Dedi dan Nurhadi Kusuma. 2019. Pengaruh Struktur Modal dan Ukuran Perusahaan terhadap Nilai Perusahaan. Jurnal Aktual STIE Trisna Negara, Vol. 17, No. 1, ISSN: 1693-1688, hal: 66-81.

Jogiyanto. 2008. Teori Portofolio dan Analisis Investasi, Edisi Kelima. BPFE: UGM.

Kasmir. 2013. Analisis Laporan Keuangan, Edisi Satu. Jakarta: PT Rajagrafindo Persada.

Languju, Octavia, dkk. 2016. Return on Asset, Ukuran Perusahaan, Price Earning Ratio, dan Struktur Modal terhadap Nilai Perusahaan Property and Real Estate yang terdaftar di Bursa Efek Indonesia. Jurnal Berkah Ilmiah Efisiensi, Vol. 16, No. 2, hal: 387-398.

Meidiawati, Karina dan Titik Mildawati. 2016. Pengaruh Size, Growth, Profitabilitas, Struktur Modal, Kebijakan Dividen terhadap Nilai Perusahaan. Jurnal Ilmu dan Riset Akuntansi, Vol. 5, No. 2, ISSN: 2460-0585.

Modigliani, F dan M. H. Miller. 1963. Corporate Income Taxes and The Cost of Capital: A Correction. The American Economic Review 53 (3), pp: 433-434.

Myers, S. C. 2001. Capital Structure. Journal Of Economic Perspective. Spring, 5 (2): h: 81 102.

Najmudin. 2011. Manajemen Keuangan dan Aktualisasi Syar'iyyah Modern. Yogyakarta: Penerbit Andi.

Novari, P. M dan Putu Vivi Lestari. 2016. Pengaruh Ukuran Perusahaan, Leverage, dan Profitabilitas terhadap Nilai Perusahaan Pada Sektor Properti dan Real Estate. E-Jurnal Manajemen Unud, Vol. 5, No. 9, ISSN: 2302-8912, hal: 5671-5694.

Pantow, M. S, dkk. 2015. Analisa Pertumbuhan Penjualan, Ukuran Perusahaan, Return on Asset, dan Struktur Modal terhadap Nilai Perusahaan yang Tercatat di Indeks LQ 45. Jurnal EMBA. Vol. 3, No. 1, ISSN: 2303-1174, hal: 961-971.

Permatasari, Cynthia. 2019. Pengaruh Likuiditas, Struktur Modal, Dan Ukuran Perusahaan terhadap Nilai Perusahaan. Jurnal Ilmu dan Riset Manajemen, Volume 1, ISSN: 24610593.

Prastuti, N. K. R dan I. G. Merta Sudiartha. 2016. Pengaruh Struktur Modal, Kebijakan Dividen, dan Ukuran Perusahaan terhadap Nilai Perusahaan pada Perusahaan Manufaktur. E-Jurnal Unud, Vol. 5, No. 3, ISSN: 2302-8912.

Ramadhonah, Zahrah, dkk. 2019. Pengaruh Struktur Modal, Ukuran Perusahaan, Pertumbuhan Perusahaan, dan Profitabilitas terhadap Nilai Perusahaan Pada Perusahaan Sektor Pertambangan yang terdaftar di BEI. Jurnal Riset Akuntansi dan Keuangan. Vol. 7, No. 2.

Riyanto, Bambang. 2001. Dasar - Dasar Pembelanjaan Perusahaan (Edisi Keempat). Yayasan 
Penerbit Gajah Mada.

Rudangga, I. G. N. G dan G. M. Sudiarta. 2016. Pengaruh Ukuran Perusahaan, Leverage, dan Profitabilitas terhadap Nilai Perusahaan. E-Jurnal Unud, Vol. 5, No. 7, ISSN: 23028912, hal: 4394-4422.

Rukmawanti, Lita, dkk. 2019. Pengaruh Ukuran Perusahaan dan Profitabilitas terhadap Nilai Perusahaan. Businnes Management And Enterpreneurship Journal, Vol. 1, No. 2.

Sartono. 2001. Manajemen Keuangan Teori dan Aplikasi, Edisi Keempat. BPFE: Yogyakarta.

Sawir, Agnes. 2004. Analisis Kinerja Keuangan dan Perencanaan Keuangan Perusahaan. PT Gramedia Pustaka Utama.

Setia, Lukas. 2008. Teori Praktik Manajemen Keuangan. Yogyakarta: Andi.

Situmeang, Y. M. L dan N. L. P. Wiagustini. 2018. Pengaruh Struktur Modal terhadap Nilai Perusahaan Dengan Kebijakan Hedging Sebagai Mediasi Pada Perusahaan BUMN GoPublic. E-Jurnal Unud, Vol. 7, No. 3, ISSN: 2302-8912, hal: 1368-1396.

Siregar, M. E. S, dkk. 2019. Pengaruh Profitabilitas, Ukuran Perusahaan, Kebijakan Dividen, dan Struktur Modal terhadap Nilai Perusahaan Pada Perusahaan Manufaktur yang terdaftar di Bursa Efek Indonesia Tahun 2015-2017. Jurnal Riset Manajemen Sains Indonesia (JRMSI), Vol. 10, No. 2, ISSN: 2301-8313.

Sudarmaji, A. M., dan Lana Sularto. 2007. Pengaruh Ukuran Perusahaan, Profitabilitas, Leverage, dan Tipe Kepemilikan Perusahaan terhadap Luas Voluntary Disclosure Laporan Keuangan Tahunan. Proceeding PESAT (Psikologi, Ekonomi, Sastra, Arsitek \& Sipil), Vol. 2, ISSN: 1858-2559.

Sudarmanto, R. Gunawan. 2005. Analisis Regresi Linier Berganda dengan SPSS. Yogyakarta: Ghalia Ilmu.

Sunyoto, Danang. 2007. Analisis Regresi dan Korelasi Bivariat Ringkasan dan Kasus. Yogyakarta: Amara Books.

Suranta, E., dan P. P. Mediastuty. 2003. "Analisis Hubungan Struktur Kepemilikan Manajerial Nilai Perusahaan dan Investasi Dengan Model Persamaan Linier Simultan". Jurnal Riset Akuntansi Indonesia, Vol. 6, No. 1, hal: 54-68.

Susanto, Edy. 2016. Pengaruh Profitabilitas, Kepemilikan Manajerial, Dan Petumbuhan Perusahaan (Growth) terhadap Struktur Modal dan Nilai Perusahaan. Jurnal STIE Semarang, Vol 8, hal: 1-20.

Suseno, I. 2012. Faktor - Faktor yang Berpengaruh terhadap Nilai Perusahaan Pada Perusahaan Manufaktur Go Public yang Terdaftar di BEI.

Ukhriyawati, C. F dan Riani Dewi. 2019. Pengaruh Struktur Modal, Pertumbuhan Perusahaan, dan Ukuran Perusahaan terhadap Nilai Perusahaan pada Perusahaan LQ-45 yang terdaftar di Bursa Efek indonesia. Jurnal Equilibiria, Vol. 6, No. 1, ISSN: 2503 1546.

Undang-Undang No. 20 Tahun 2008 tentang Usaha Mikro, Kecil, Menengah, dan Besar.

Utomo, Nanang Ari dan N. N. A. Cristy. 2017. Pengaruh Struktur Modal, Profitabilitas, Ukuran Perusahaan terhadap Nilai Perusahaan Pada Perusahaan LQ 45 di Bursa Efek Indonesia. Jurnal Bingkai Manajemen.

Wijoyo, Amin. 2018. Faktor-Faktor Yang Mempengaruhi Nilai Perusahaan Pada Perusahaan 
Property dan Real Estate di BEI. Junal Ekonomi, Vol. 23, No. 1.

Wongso, A. 2012. Pengaruh Kebijakan Deviden, Struktur Kepemilikan, dan Kebijakan Hutang terhadap Nilai Perusahaan dalam Perspektif Teori Agensi dan Teori Signaling, h: $1-6$.

Yanti, I. G. A. D. N dan N. P. A Darmayanti. 2019. Pengaruh Profitabilitas, Ukuran Perusahaan, Struktur Modal, Dan Likuiditas terhadap Nilai Perusahaan Pada Perusahaan Makanan dan Minuman. E-Jurnal Manajemen Unud, Vol. 8, No. 4, ISSN: 2302-8912, hal: 2297-2324. 